\title{
Pre-service Science Teachers' Perception of the Principles of Scientific Research
}

\author{
Şendil Can ${ }^{1}$, Güliz Kaymakci ${ }^{2}$ \\ ${ }^{1}$ Education Faculty, Mugla Sitki Kocman University, Mugla, Turkey \\ ${ }^{2}$ Education Faculty, Mugla Sitki Kocman University, Mugla, Turkey \\ Correspondence: Şendil Can, Department of Science Education, Education Faculty, Mugla Sitki Kocman University, \\ Muğla, 48000, Turkey.
}

Received: July 21, 2016

doi:10.11114/jets.v4i10.1758
Accepted: August 16, $2016 \quad$ Online Published: September 5, 2016

URL: http://dx.doi.org/10.11114/jets.v4i10.1758

\begin{abstract}
The purpose of the current study employing the survey method is to determine the pre-service science teachers' perceptions of the principles of scientific research and to investigate the effects of gender, grade level and the state of following scientific publications on their perceptions. The sampling of the current research is comprised of 125 pre-service science teachers attending the Department of Science Teaching in Muğla Sttkı Koçman University in the spring term of 2014-2015 academic year. As the data collection instruments, Information Form to elicit the demographic characteristics of the pre-service teachers and five-point Likert type "Scale of Scientific Research Principles" developed by Campell, Abd-Hamid and Chapman in 2010 and adapted to Turkish by Tatar, Feyzioğlu, Buldur and Aydoğdu (2014) were employed. Frequencies and percentages were calculated for their perceptions of the principles of scientific research, t-test was run to test whether the pre-service teachers' perceptions vary significantly depending on gender and grade level variables and one-way variance analysis was used to test whether their perceptions vary significantly depending on their state of following scientific publications. At the end of the study, it was found that the pre-service teachers' perception levels of the principles of scientific research are high, their perceptions of the principles of scientific research vary significantly depending on gender variable in favor of male participants; however, their grade level and state of following scientific publications do not have significant effect on their perceptions.
\end{abstract}

Keywords: scientific research principles, science teaching, pre-service teacher, scientific publication, variance analysis

\section{Introduction}

It is a fact that science and technology shape educational and instructional strategies of countries in the long run. Information societies aim to educate generations that can research, investigate, question, criticize, solve the problems of their era and more importantly can produce (Tatar, 2006). Laying the basis of scientific disciplines and technology, science can be defined as systematically examining observable nature and natural phenomena and an attempt to predict the events that have not been observed yet (Doğru and Kıyıc1, 2005). Many abstract concepts are involved in science and technology education and individuals experience difficulties while learning these concepts. Therefore, in science education students are not expected to have information level needed to explain a scientific phenomenon (Dagher, 1995). Inquiry-based learning; on the other hand, allows students and teachers to investigate the natural world and use the collected data by testing the perceived concepts thus to reify the abstract concepts (Tatar, 2006). In this regard, inquiry-based learning is a strategy quite different from receiving information from teachers or textbooks and constructed experiments and activities conducted by students (Çelik et al, 2005). For this strategy to be effective, its steps should be followed during its application and thus the scientific nature of the research can be improved (Çepni, 2009). Hampton and Licona (2001) argue that science and research refer to a long-termed period generally emerging together with the process.

For a study to reach accurate, valid and reliable information, it should possess some characteristics. These characteristics can be subsumed under four headings (AÖF, 2011);

a) Objectivity; it can be defined as, during a research process, the researcher's not letting his/her own opinions and expectations affect the research but in the interpretation and evaluation of the findings, his/her explaining his/her own objectives, habits and beliefs as they are so that the results can be presented so clearly that they can be understood by everyone in a similar manner. 
b) Accuracy and replication; accuracy means the researcher's approaching the reality as much as possible rather than showing the absolute truth and trying to express it in a most comprehensible and proper way. Reliability/replication on the other hand means that a researcher's findings can be completely or partially replicated by other researchers.

c) Simplicity and clarity; means that the concepts should be explained and the aspects of the used concepts different from other concepts should be expressed.

d) Limitation; means that the characteristics differentiating the subject under investigation from other subjects should be determined and thus its border should be drawn.

When the relevant literature is examined, it is seen that the principles of scientific research are addressed under the heading of inquiry-based learning. Researchers such as Arslan (2007), Ortakuz (2006), Uludağ (2003), Samanc1 and Bozkurt (2010) reported significant and positive developments in favor of the academic achievements of the experimental groups engaged in inquiry-based learning. Inquiry-based instruction offers many advantages for teachers as well as students. It provides opportunities for teachers to establish effective interaction with each student, to provide guidance for students, to encourage students to see and understand the world through a scientific viewpoint and to help students to develop the skills and attitudes required for them to conduct inquiries on their own (Bass, Contant and Carin 2009:3). It is of great importance for teachers to possess information and skills to teach science by means of inquiry. For this purpose, it seems to be necessary to determine the pre-service science teachers' perceptions of the principles of scientific research. When the literature is reviewed, it is seen that there is a paucity of research on this issue. Therefore, the current study is believed to help the pre-service teachers to acquire viewpoints about instructional practices they will be engaged in when they become teachers and to fill the gap in the literature.

In this regard, determination of the prospective teachers' perceptions of the principles of the scientific research seems to be importance. Therefore, answers to the following questions were sought in the current study:

$>$ What is the pre-service teachers' perception level of the principles of scientific research?

$>$ Do the pre-service teachers' perceptions of the principles of scientific research vary significantly depending on

a) Gender

b) Grade level

c) The state of following scientific publications (TUBITAK publications, scientific articles, TV program with scientific content)?

\section{Method}

Survey method was used in the current study. Survey method is used to elicit the selected group's attitudes, beliefs and opinions about a certain topic (McMillan and Schumacher, 2006).

\subsection{Sampling}

The sampling of the current study consists of 125 pre-service science teachers attending the Department of Science in the Education Faculty of Mugla Sitki Kocman University.

\subsection{Data Collection Instruments}

In the current study, an Information Form developed by the researchers to elicit the demographic features of the participants and a five-point Likert type "Scale of Scientific Research Principles" published by Campell, Abd-Hamid and Chapman (2010) in the Journal of Science Teacher Education in 2010 and adapted to Turkish by Tatar, Feyzioğlu, Buldur and Aydoğdu (2014) were used to collect data. The Scale of Scientific Research Principles consists of 20 items based on the principles of forming research questions, planning research, conducting research, collecting data and reporting results and one sub-factor. The scale is comprised of five categories with the themes of "Formation of research questions in classes", "Planning of research in science classes", "Conducting research in science classes", "Collecting data in science classes", "Reporting of results in science classes" and in each category, there are four items. In order to determine the internal reliability of the scale items, Cronbach alpha internal consistency coefficient calculated by Tatar et al. (2014) is .96. Cronbach alpha internal reliability coefficient calculated on the basis of the data collected in the current study is .88 .

\subsection{Data Analysis}

The distribution of the pre-service science teachers' perceptions of the principles of scientific research was determined through descriptive statistics, t-test was run to determine whether the pre-service science teachers' perceptions of the principles of scientific research vary significantly depending on gender and grade level and whether their perceptions vary significantly depending on the state of following scientific publications was determined with One Way ANOVA. In the analysis of the data, SPSS 20.0 program package was used. The items in the scale were scored as follows: Completely Disagree:1, Disagree:2, Undecided:3, Agree:4, Completely Agree:5. 


\section{Findings}

In this section, the findings related to the sub-problems of the research are presented in tables and then interpreted.

\subsection{Findings Related to the First Sub-problem}

The first sub-problem of the study requires the determination of the pre-service science teachers' perception levels of the principles of scientific research. In this regard, frequencies and percentages are given in Table 1 to show the pre-service science teachers' perception levels of the principles of scientific research.

Table 1. Pre-service science teachers' perception levels of the principles of scientific research

\begin{tabular}{ccccccc}
\hline & Low & & \multicolumn{2}{c}{ Medium } & \multicolumn{3}{c}{ High } \\
\hline $\mathrm{N}$ & $\%$ & $\mathrm{~N}$ & $\%$ & $\mathrm{~N}$ & $\%$ \\
1 & 0.8 & 42 & 33.6 & 82 & 65.6 \\
\hline
\end{tabular}

When Table 1 is examined, it is seen that $8 \%$ of the pre-service science teachers have low perception level of the principles of scientific research, $33.6 \%$ have medium perception level and $65.6 \%$ have high perception level.

Thus, it can be concluded that when the pre-service science teachers become teachers, they will have positive attitudes towards inquiry-based applications.

\subsection{Findings Related to the Second Sun-problem}

T-test results related to the pre-service science teachers' scores taken from the "Scale of Scientific Research Principles" in relation to gender variable are given in Table 2.

Table 2. Gender-related t-test results for the pre-service science teachers' perceptions of the principles of scientific research

\begin{tabular}{lllllll}
\hline Gender & $\mathrm{N}$ & $\overline{\mathrm{x}}$ & $\mathrm{S}$ & $\mathrm{sd}$ & $\mathrm{t}$ & $\mathrm{p}$ \\
\hline Female & 80 & 72.37 & 9.94 & 123 & -3.338 & .001 \\
Male & 45 & 78.60 & 10.03 & & &
\end{tabular}

As can be seen in Table 2, of the participants, 80 are females and 45 are males. It is seen that the pre-service teachers' perceptions of the principles of scientific research vary significantly depending on gender $\left[\mathrm{t}_{(123)}=-3.338, \mathrm{p}<.05\right]$ and this difference is in favor of male pre-service teachers $(\mathrm{X}=78.60)$.

\subsection{Findings Related to the Third Sub-problem}

T-test results related to the pre-service science teachers' scores taken from the "Scale of Scientific Research Principles" in relation to grade level variable are given in Table 3.

Table 3. Grade level-related t-test results for the pre-service science teachers' perceptions of the principles of scientific research

\begin{tabular}{lllllll}
\hline Grade level & $\mathrm{N}$ & $\overline{\mathrm{X}}$ & $\mathrm{S}$ & $\mathrm{sd}$ & $\mathrm{t}$ & $\mathrm{p}$ \\
\hline 1 & 66 & 77.50 & 10.42 & 123 & 1.451 & .149 \\
3 & 57 & 74.77 & 10.35 & & & \\
\hline
\end{tabular}

As can be seen in Table 3, of the participating pre-service teachers, 66 are first-year students and 57 are third-year students. It is seen that the pre-service science teachers' perceptions of the principles of scientific research do not vary significantly depending on the grade level variable $\left[\mathrm{t}_{(123)}=1.451, \mathrm{p}>.05\right]$.

\subsection{Findings Related to the Fourth Sub-problem}

Arithmetic means and standard deviations related to the pre-service science teachers' scores taken from the "Scale of Scientific Research Principles" in relation to the state of following scientific publications are given in Table 4.

Table 4. Arithmetic means and standard deviations related to the correlation between the pre-service science teachers' perceptions of the principles of scientific research and their state of following scientific publications

\begin{tabular}{llll}
\hline State of following scientific publications & $\mathrm{N}$ & $\overline{\mathrm{X}}$ & $\mathrm{S}$ \\
\hline Frequently & 12 & 80.50 & 9.29 \\
Sometimes & 85 & 76.91 & 10.53 \\
Never & 28 & 72.89 & 9.78 \\
\hline
\end{tabular}


As can be seen in Table 4, the pre-service teachers' frequency of following scientific publications is as follows: 12 pre-service teachers frequently follow them, 85 of them sometimes, and 28 never. In general it is seen that the mean score of the pre-service teachers stating that they frequently follow scientific publications ( $\bar{X}=80.50)$ is higher than that of the other participants and the mean score of the pre-service teachers stating that they never follow scientific publications $(\bar{X}=72.89)$ is lower than that of the other participants.

In order to determine whether the difference between the arithmetic means is statistically significant, one way variance analysis was conducted and ANOVA results related to the correlation between the pre-service science teachers' scores taken from the "Scale of Scientific Research Principles" and their state of following scientific publication are presented in Table 5.

Table 5. ANOVA results related to the correlation between the pre-service science teachers' perceptions of the principles of scientific research and their state of following scientific publications

\begin{tabular}{llllll}
\hline Source of variance & Sum of squares & sd & Mean of squares & F & P \\
\hline Between-groups & 568.698 & 2 & 284.349 & & \\
Within-groups & 12852.102 & 122 & 105.345 & 2.699 & .071 \\
Total & 13420.800 & 124 & - & & \\
\hline
\end{tabular}

The analysis results presented in Table 5 show that there is no statistically significant correlation between the pre-service science teachers' perceptions of the principles of scientific research and their state of following scientific publications $\left[\mathrm{F}_{(2-122)}=2.699, \mathrm{p}>.05\right]$.

\section{Results}

The results obtained through this study conducted to determine the pre-service teachers' perceptions of the principles of scientific research can be summarized as follows:

1) In general, the pre-service science teachers' perception levels of the principles of scientific research were found to be high.

2) The pre-service science teachers' perceptions of the principles of scientific research vary significantly depending on their gender; however, they do not vary significantly depending on grade level and the state of following scientific publications.

\section{Discussion}

It was concluded that the pre-service science teachers' perceptions of the principles of scientific research vary significantly depending on the gender variable. When the literature is reviewed, it is seen that researchers such as Lee et al. (2004), Brown and Melear (2006), Crawford (2007) also reported that gender variable leads to significant differences. These studies support this finding of the current study. There are some other studies that do not support this finding in the literature. Schwarz and Gwekwerere (2007), Varma (2007), Duncan, Pilitsis and Piegaro (2010) concluded that gender variable does not lead to significant differences in terms of inquiry-based education and accordingly the principles of scientific research. These studies are not parallel to this finding of the current study. This finding can be interpreted as the male students are better in forming research questions, planning research, conducting research, collecting data and reporting results than the female students.

Furthermore, it was concluded that the pre-service science teachers' perceptions of the principles of scientific research do not vary significantly depending on grade level. Thus, it can be argued that the pedagogical content area courses taken in the first year and in the third year and applications conducted in these courses do not affect these perceptions of the students. Tatar et al. (2014) reported a significant difference between the first year students and the students from the other grade levels in favor of the students from higher grades.

The state of following scientific publications was found to be not affecting the pre-service science teachers' perceptions of the principles of scientific research. In other words, the state of following scientific publications does not affect the stages of forming questions, planning research, conducting research, collecting data and reporting results. When the literature was reviewed, no study examining the relationship between the perception of the principles of scientific research and the state of following scientific research was encountered.

\section{Suggestions}

In light of the findings of the current study, following suggestions can be made:

1. As there is a paucity of research addressing pre-service science teachers' perceptions of the principles of scientific research in our country, there is a need for research in this field. In this regard, further research can be designed by using 
different data collection instruments and methods to determine pre-service teachers' perceptions and to gather more detailed information.

2. In education faculties, inquiry-based instructional activities should be integrated into courses so that students may enhance their perceptions in this field.

3. Conducting studies in this field with different variables and samplings may be effective in improving the perception of the principles of scientific research.

4. It is believed that encouraging students to follow scientific publications may contribute to the development of positive perceptions of the principles of scientific research.

\section{References}

AFÖ (2011). Açık öğretim fakültesi sosyoloji ders notları. 05.02.2016 tarihinde www.aofsosyoloji.com adresinden ulaşılmıştır.

Arslan, A. (2007). Fen eğitiminde araştırmaya dayalı öğretim yönteminin kavramsal öğrenmeye etkisi. Yayımlanmamış Yüksek Lisans Tezi. Marmara Üniversitesi, Eğitim Bilimleri Enstitüsü: İstanbul.

Bass, E. J., Contant L. T., \& Carin A. A. (2009). Methods for teaching science as inquiry. USA: Pearson Press.

Brown, L. S., \& Melear, T. C. (2006). Investigation of secondary science teachers' beliefs and practices after authentic inquiry-based experiences. Journal of research in science teaching, 43(9), 938-962. http://dx.doi.org/10.1002/tea.20110

Campell, T., ABD-Hamid, N. H., \& Chapman, H. (2010). Development of instruments to assess teacher and student perceptions of inquiry experiences in science classrooms. Journal of science teacher education, 21, 13-30. http://dx.doi.org/10.1007/s10972-009-9151-x

Crawford, A. B. (2007). Learning to teach science as inquiry in the rough and tumble of practice. Journal of research in science teaching, 44(4), 613-642. http://dx.doi.org/10.1002/tea.20157

Çelik, S., Şenocak, E., Bayrakçeken, S., Taşkesenligil, Y., \& Doymuş, K. (2005). Aktif öğrenme stratejileri üzerine bir derleme çalışması. Kazım Karabekir eğitim fakültesi dergisi, 11, 155-185.

Çepni, S. (2009). Araştırma ve proje çalışmalarına giriş (4. baskı). Trabzon: Celepler Matbaacılık.

Dagher, Z. R. (1995). Analysis of analogies used by science teachers. Journal of research in science teaching, 32, 259-270. http://dx.doi.org/10.1002/tea.3660320306

Doğru, M., \& Kıyıcı, F. B. (2005). Fen eğitiminin zorunluluğu. Aydoğdu ve Kesercioğlu (Ed). İlköğretimde fen ve teknoloji öğretimi (Pp. 1-8). Ankara: Anı Yayıncıllk. ISBN: 975-6376-54-6.

Duncan R. G., P1litsis, V., \& Piegaro, M. (2010). Development of preservice teachers' ability to critique and adapt inquiry-based instructional materials. Journal of science teacher education, 21, 81-102. http://dx.doi.org/10.1007/s10972-009-9153-8

Hampton, E., \& Licona, M. (2001). An Emerging Understanding of Scientific Literacy: Moving Toward A Curriculum Of Inclusion. Electronic Journal of Literacy Trough Science, 1(1).

Lee, O. V. D. (2004). Professional development in inquiry-based science for elementary teachers of diverse student groups, Journal of research in science teaching, 41(10), 1021-1043. http://dx.doi.org/10.1002/tea.20037

McMillan, H., \& Schumacher, S. (2006). Researching in education evidence-based inquiry. 6th Edition, Boston: Allyn and Bacon Inc.

Ortakuz, Y. (2006). Araştırmaya dayalı öğrenmenin öğrencilerin fen-teknoloji-toplum-çevre ilişskisini kurmasina etkisi. Yüksek Lisans Tezi. Marmara Üniversitesi, Eğitim Bilimleri Enstitüsü: İstanbul.

Samanc1, N. K., \& Bozkurt, O. (2010). An alternative tool for inquiry based learning: -T Diagram, World applied science journal, 9(4), 385-392.

Schwarz, V. C., \& Gwekwerere, N. Y. (2007). Using a guided inquiry and modeling instructional framework (eıma) to support preservice k-8 science teaching, Science education, 91(1), 158-186. http://dx.doi.org/10.1002/sce.20177

Tatar, N. (2006). Illköğretim fen eğitiminde araştırmaya dayalı ögrenme yaklaşımının bilimsel süreç becerilerine, akademik başarlya ve tutuma etkisi. Doktora Tezi. Gazi Üniversitesi, Eğitim Bilimleri Enstitüsü. Ankara.

Tatar, N., Feyzioğlu, E. Y., Buldur, S., \& Aydoğdu, B. (2014). Fen bilgisi öğretmen adaylarının araştırmaya dayalı eğitime yönelik algıları: Bilimsel araştırmanın ilkeleri ölçeği. OMÜ Ĕğ. Fak. Derg./OMU J. Fac. Educ., 33(2), 577-592. http://dx.doi.org/10.7822/omuefd.33.2.17. 
Uludağ, Ö. (2003). İlköğretim beşinci sınıf sosyal bilgiler dersinde araştırma-inceleme yoluyla ögretim ve geleneksel öğretimin akademik başarıya etkisi. Yüksek lisans tezi, Çukurova Üniversitesi Sosyal Bilimler Enstitüsü, Adana.

Varma, T. (2007). Preservice elementary teachers' perceptions of their understanding of scientific inquiry-based pedagogy and their confidence to teach science: influence of elementary science education methods course and science field experience. University of Missouri, y.d.t., Columbia

\section{$(\mathrm{cc}) \mathrm{BY}$}

This work is licensed under a Creative Commons Attribution 3.0 License. 